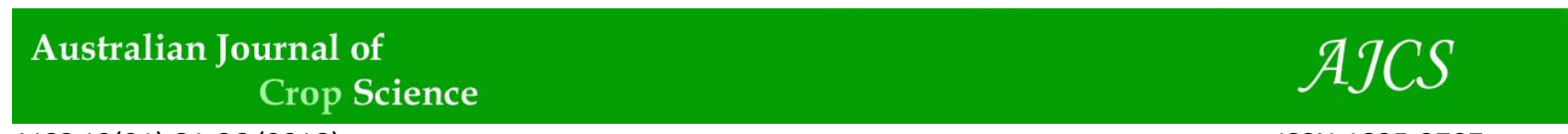

AJCS 12(01):81-86 (2018)

ISSN:1835-2707

doi: 10.21475/ajcs.18.12.01.pne710

\title{
Quality of strawberry seedlings can determine precocity
}

\section{Rosiani Castoldi da Costa , Eunice Oliveira Calvete, Fabiola Stockmans DeNardi, Ana Cláudia Pedersen, José Luís Trevizan Chiomento, Nicolas dos Santos Trentin}

University of Passo Fundo, Faculty of Agronomy and Veterinary Medicine, Campus I-Barrio San José - BR 285 - Km 171, CEP :99052-900, 611 Pillar Box - Passo Fundo, Rio Grande do Sul, Brazil.

\section{*Corresponding author: rosianicastoldi@yahoo.com.br}

\begin{abstract}
The development of day-neutral (DN) strawberry cultivars and their relationship with the quality of strawberry seedlings are important for the identification of precocity, ie. early flowering and fruiting. This study aimed to test whether the variability between morphoagronomic DN strawberry cultivars is associated with precocity. The treatments were four cultivars of strawberry (Albion, Aromas, Portola and San Andreas), and three plant crown diameters $(\varnothing \mathrm{B}<8 \mathrm{~mm}, \varnothing \mathrm{A}$ between 8.1 and $12 \mathrm{~mm}$ and $\varnothing \mathrm{A}+>$ $12 \mathrm{~mm}$ ). The design was completely randomized with five replications under split plot scheme. The plants were grown in plastic containers filled with commercial substrate. The analyzed variables were the phenological stages, thermal sum accumulated (TSa) and phyllochron. The phenological data were submitted to multivariate analysis. The phyllochron $\left({ }^{\circ} \mathrm{C}\right.$ day leaf $\left.{ }^{-1}\right)$ was estimated as the inverse angular coefficient of linear regression. Aromas $\varnothing \mathrm{B}$ and Portola $\varnothing \mathrm{A}$ were the most divergent. Aromas and San Andreas $\varnothing A+$ were earlier maturity with phyllochron of 89.28 and $85.47 \circ \mathrm{C}$, respectively. Phenological stage 71 demonstrated larger relative contribution for separation of the groups according to the crown diameter. The quality of seedlings for DN cultivars is determined by the crown diameter $(>8.1 \mathrm{~mm})$.
\end{abstract}

Keywords: Fragaria $\mathrm{x}$ ananassa Duch.; crown diameters; phenology; phyllochron; multivariate analysis.

Abbreviation: ATt_Accumulated thermal time; bT_base temperature; dmT_daily mean temperature; DN_day neutral; dTS_daily thermal sum; JD_Julian day; LN leaf number; TSa thermal sum accumulated.

\section{Introduction}

The strawberry (Fragaria $\mathrm{x}$ ananassa Duch.) presents wider distribution than many other small fruits and is among the most consumed fruits worldwide (Gonçalves et al., 2017). This is due to its large genotypic diversity, as well as its environmental adaptive capacity (Akhatoua et al., 2016). The culture of strawberries is spread across countries like the United States, Spain, Japan, Italy, South Korea, and Poland. In Brazil, the culture mainly occupies subtropical and temperate climate regions, where the fruits are used for in natura consumption and industrialization. In southern Brazil, the seedlings used by fruit producers are mainly developed in the Argentine and Chilean Patagonia. This complicates the availability of seedlings at the most appropriate time for planting (early fall); thereby, slowing the transplantation. Currently, the planting date is conditioned to the delivery of seedlings imported to Brazil. This situation makes it difficult to obtain early production and achieve more balanced values to the producer, ultimately reducing seasonality. There are many factors affecting the early yield of strawberries; among these are the characteristics of the cultivar, the climate, the planting season, and the type and quality of seedlings (Ledesma and Kawabata, 2016; Sønsteby et al., 2016). In recent years, there were increases in the use of seedlings from the day-neutral (DN) group because they have ability to remain in production for longer periods than cultivars of short days (SD) (Costa et al., 2016). However, this situation occurs only if temperatures do not exceed $27^{\circ} \mathrm{C}$ during flowering, because in these conditions, there is a decrease in the production of flowers (Sønsteby and Heide, 2007). Strawberry cultivars classified as DN vary in the level of reflowering, according to the place and year of growth (Durner, 2015). Some studies have shown variability between the agronomic characteristics of different cultivars in association with their precocity (Dávalos-González et al., 2014, Hidaka et al., 2017). Phenological data are important in many aspects of agriculture, because they provide basic information on the culture requirements. It is the study of the stages of development of plants and their temporal occurrence throughout the year, depending on the environmental conditions that contribute to the understanding of plant reproductive and vegetative patterns (Cascaes et al., 2013). The process of flower formation and the growth of leaves in strawberries is associated with precocity (Hidaka et al., 2017; Rahman et al., 2016). The leaves growth rate is estimated by the phyllochron that determines the interval time necessary for the emission of two consecutive leaves (Hermes et. al., 2001, Frank and Bauer, 1995). 
This study aimed to test whether the morphoagronomic variability in DN strawberry cultivars is associated with precocity.

\section{Results}

\section{Phenological stages of strawberry plant}

After analyzing the morphoagronomic characteristics in DN strawberry cultivars, it was possible to classify them into seven groups using Tocher's optimization method. Then, the variability between cultivars was compared. Aromas and San Andreas were formed group III with crown diameter larger than $12 \mathrm{~mm}$ and found to be the most precocious. They required an average Julian day (JD) to achieve the right phenological stage (Table 1).

The Albion cultivar with a diameter less than $8 \mathrm{~mm}$ to 12 $\mathrm{mm}$ was the latest. From the stage of the appearance of flower primordial, the differences between cultivars were separated. However, the stage in which the receptacle started its development (stage 71 ) represented the most significant relative contribution $(90 \%)$ among the other phases, in terms of divergence between the distinct groups formed by the cultivars in response to precocity (Table 2).

Calculation of the $\mathrm{D}^{2}$ showed that Albion and Aromas seedlings, classified as $A^{+}(>12 \mathrm{~mm}$ ) are similar in terms of their phenological attributes. Meanwhile, Aromas seedlings with a crown less than $8 \mathrm{~mm}$ and Portola seedlings with a crown larger than $12 \mathrm{~mm}$ were the most divergent (Table 3 ).

\section{Thermal sum accumulated from the transplant to the fruit} harvest.

Associating the seven groups with the TSa in each phenological stage, the group formed by Aromas $\mathrm{A}^{+}$and San Andreas $\mathrm{A}^{+}$required $346^{\circ} \mathrm{C}$ for phase changes to obtain the harvest of the main flower. In terms of precocity, we found that Albion $\mathrm{A}^{+}$, Aromas A, Portola $\mathrm{A}^{+}$and San Andreas A were similar to this group. Group I (Albion B and A) needed an average of $430^{\circ} \mathrm{C}$ to reach harvest and was considered the most tardy (Fig 1).

\section{Phyllochron required to emerge two consecutive leaves}

Aromas $\mathrm{A}^{+}$with 0.0112 leaves per each 으 day accumulated needed phyllochron of $89.28^{\circ} \mathrm{C}$ to emerge two consecutive leaves. However, San Andreas $\mathrm{A}^{+}$with 0.0117 accumulated leaf per 을 day, needed phyllochron of $85.47 \stackrel{\circ}{\circ}$. Both cultivars belong to the group III, and they were considered to be most precocious because they required a TSa of 265ㅇ $\mathrm{C}$ to reach stage 71 , when they presented 5.6 and 6.0 leaves, respectively (Fig 2). Meanwhile, Albion B with a lower accumulation of leaves ( 0.0072 per each ${ }^{\circ} \mathrm{C}$ day) and with that TSa had only 2.4 leaves and phyllochron of $138.88 \stackrel{\circ}{\circ}$ to emerge two consecutive leaves; thus, it was considered the most tardy.

\section{Discussion}

The results showed significant divergence between DN of strawberry cultivars, relating the attributes of phenology with precocity. Many researchers have reached this conclusion (Costa et al., 2014; Wan et al., 2014), but few have used multivariate analysis, calculation of the Mahalanobis distance, and Tocher's optimization method to verify the variability of morphoagronomic characteristics associated with precocity. The quality of seedling, given by the higher $\mathrm{C} / \mathrm{N}$ ratio on the crown of DN strawberry cultivars had a positive influence on plant development, preceding the beginning of harvest by up to 13 days. Crown diameters greater than $8.1 \mathrm{~mm}$ resulted in more precocious cultivars. The highlights in this attribute were the cultivars gathered in the groups II, III, and IV.

The low quality of the material in transplantation is the main limiting factor of the strawberry crop (Torres-Quezada et al., 2015). Components like genotype (Rahman et al., 2016), crown diameter (Torres-Quezada et al., 2015), initial weight of the plant (Bartczak et al., 2010) and number of leaves (Costa et al., 2014) can influence plant development. Greater vegetative growth is associated with higher growth rates, especially in leaf area, thereby increasing the drainsource ability and enhancing the quality of seedling (Rosa et al., 2011). We emphasize that photoassimilates stored in the crown represent an important factor to be considered in the production of strawberry fruits. This is because their diameter is the main characteristic used to determine the quality of strawberry seedlings, and they must present a diameter greater than $8 \mathrm{~mm}$ (Torres-Quezada et al., 2015).

The difference between the groups was described when the strawberry plants passed the appearance of flower primordial at the base of the rosette (stage 55) for first open flowers (stage 60), and when posteriorly reached the phase where the receptacle emerged from the sepal's crown (stage 71). This is related to the days needed for the cultivars to complete their cycle.

The result of stage 71 was definitive for the identification of cultivars with higher precocity. If we consider the beginning of leaf emission for cultivars identified as precocious, crowns with a diameter larger than $12 \mathrm{~mm}$ have greater ability to mobilize reserves to start the apprearance of leaves and axillary buds that turn into flower buds. Because of this, when stage 71 is reached, the precocious cultivars already present 5.6-6 leaves (Aromas and San Andreas $\mathrm{A}^{+}$, respectively) with a thermal sum of $265^{\circ} \mathrm{C}$, justifying the beginning of fruit formation beforehand. The cultivar Albion B is considered tardier (slow), as this stage and TSa showed only 2.4 leaves. This induced less nutrient mobilization capacity for the formation of fruit. In strawberry, there is a high correlation between leaf number and number of fruits because many axillary buds develop into flower buds (Rosa et al., 2013). This justifies identification of precocity in cultivars with a larger crown diameter, reaching faster to stage 71 .

Although all cultivars were considered DN, there were mainly differences between Aromas $B$ and Portola $A^{+}$when considering the phenology and crown diameter of plants, where the value of $D^{2}$ was maximal $\left(D^{2}=4.672322\right)$. The formation of groups may represent valuable information for the choice of parents in breeding programs, because the new hybrid populations to be established must be based on the magnitude of their distances and the "per se" potential of parents (Bertan et al., 2006). The similarity or dissimilarity between cultivars permits identification of parents to obtain crossings with a stronger heterotic effect; thereby, increasing the chance to obtain superior individuals (Cruz 
Table 1. DN strawberry cultivars crown with different crown diameters, grouped by Julian days by Tocher optimization method.

\begin{tabular}{|c|c|c|c|c|c|c|}
\hline \multirow{2}{*}{\multicolumn{2}{|c|}{ Groups }} & \multicolumn{5}{|c|}{ Phenological stages* } \\
\hline & & 11 & 55 & 60 & 71 & 87 \\
\hline & & \multicolumn{5}{|c|}{ Julian Days (JD) } \\
\hline I & Albion $B$ and $A$ & $212.7 \pm 1.0$ & $234.0 \pm 2.8$ & $244.0 \pm 2.3$ & $253.0 \pm 1.1$ & $274.8 \pm 14.4$ \\
\hline II & Albion $\mathrm{A}^{+}$and Aromas $\mathrm{A}$ & $213.2 \pm 1.6$ & $227.2 \pm 1.1$ & $239.6 \pm 0.0$ & $247.7 \pm 3.0$ & $263.1 \pm 5.7$ \\
\hline III & Aromas $\mathrm{A}^{+}$and San Andreas $\mathrm{A}^{+}$ & $213.4 \pm 2.0$ & $227.3 \pm 1.0$ & $240.1 \pm 0.1$ & $249.1 \pm 0.7$ & $261.8 \pm 5.9$ \\
\hline IV & Portola $\mathrm{A}^{+}$and San Andreas A & $213.4 \pm 0.0$ & $229.2 \pm 0.0$ & $241.4 \pm 0.3$ & $248.2 \pm 0.3$ & $262.4 \pm 2.8$ \\
\hline V & Aromas B and Portola B & $213.4 \pm 0.0$ & $229.7 \pm 2.7$ & $239.4 \pm 1.4$ & $251.0 \pm 2.0$ & $270.7 \pm 10.6$ \\
\hline VI & Portola A & $212.0 \pm 0.0$ & $233.4 \pm 0.0$ & $245.4 \pm 0.0$ & $252.4 \pm 0.0$ & $270.0 \pm 0.0$ \\
\hline VII & San Andreas B & $212.0 \pm 0.0$ & $226.6 \pm 0.0$ & $238.8 \pm 0.0$ & $248.0 \pm 0.0$ & $267.2 \pm 0.0$ \\
\hline
\end{tabular}

*Stage 11, first leaf expanded; stage 55, appearance of first flower primordial at the base of the leaf rosette; stage 60, the 1st open flowers (primary); stage 71 , receptacle is jutting out from the sepal's crown; stage 87 main crop with most of the fruits red colored. Mean values followed by \pm SD.

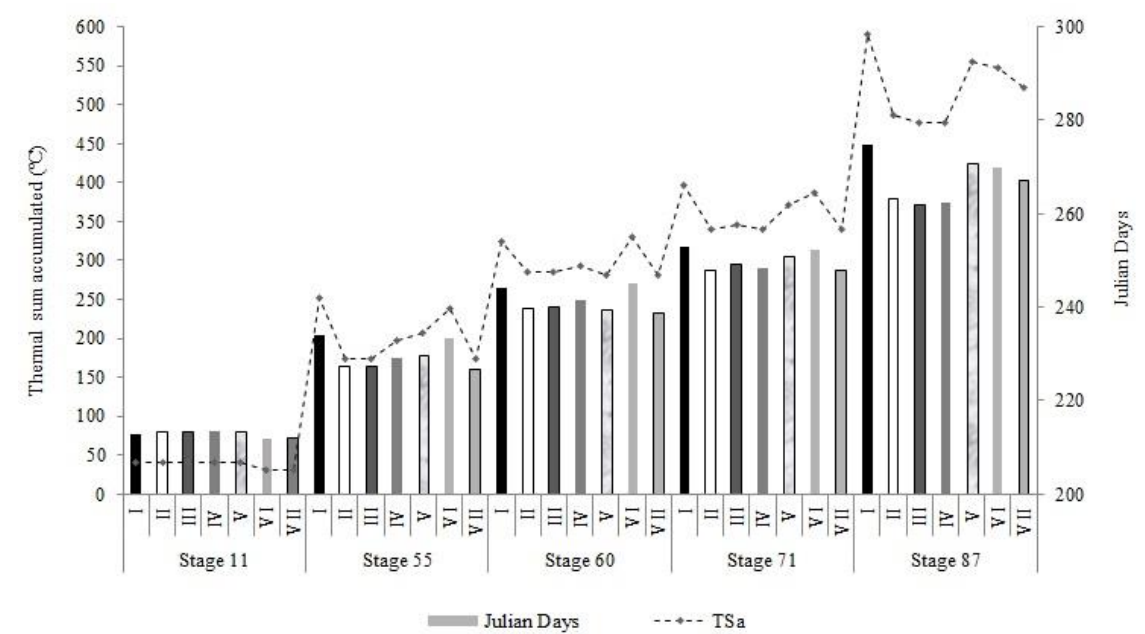

Fig 1. Accumulated thermal time (ATt) and Julian days (JD) needed for groups for each phenological stage. Stage $11=$ first leaf expanded; stage $55=$ appearance of first flower primordia at the base of the leaf rosette; stage $60=$ first open flowers (primary); stage $71=$ receptacle jutting out from the sepal's crown; stage 87 = main crop with most of the fruits red colored.

Table 2. Relative importance of characteristics $(\mathrm{Sj})$ to study the divergence between strawberry cultivars with plants that have different crown diameters.

\begin{tabular}{lcc}
\hline Phenological stages * & Sj & Sj (\%) \\
\hline 11 & 0.000001 & 0.1 \\
55 & 0.000019 & 6.2 \\
60 & 0.000001 & 0.4 \\
71 & 0.000281 & 90.1 \\
87 & 0.000009 & 2.9 \\
\hline
\end{tabular}

*Stage 11, first leaf expanded; stage 55, appearance of first flower primordial at the base of the leaf rosette; stage 60, the 1st open flowers (primary); stage 71 , receptacle jutting out from the sepal's crown; stage 87 main crop with most of the fruits red colored.

Table 3. Mahalanobis distance squared (D2) between seedlings of strawberry cultivars with different crown diameters.

\begin{tabular}{|c|c|c|c|c|c|c|c|c|c|c|c|}
\hline & Albion B & Albion A & Albion $\mathrm{A}^{+}$ & Aromas B & Aromas A & $\begin{array}{l}\text { Aromas } \\
\mathrm{A}^{+}\end{array}$ & Portola B & Portola A & Portola $\mathrm{A}^{+}$ & $\begin{array}{l}\text { San } \\
\text { Andreas B }\end{array}$ & $\begin{array}{l}\text { San } \\
\text { Andreas A }\end{array}$ \\
\hline Albion B & 0.000059 & & & & & & & & & & \\
\hline Albion $\mathrm{A}^{+}$ & 0.000023 & 0.000009 & & & & & & & & & \\
\hline Aromas B & 4.671613 & 4.671698 & 4.671653 & & & & & & & & \\
\hline Aromas A & 0.000264 & 0.000571 & 0.000442 & 4.671821 & & & & & & & \\
\hline Aromas $\mathrm{A}^{+}$ & 0.00004 & 0.000003 & 0.000002 & 4.671674 & 0.000506 & & & & & & \\
\hline Portola B & 0.000054 & 0.000223 & 0.000146 & 4.671641 & 0.00008 & 0.000183 & & & & & \\
\hline Portola A & 2.076273 & 2.07634 & 2.0763 & 0.51907 & 2.076517 & 2.076318 & 2.076316 & & & & \\
\hline Portola $\mathrm{A}^{+}$ & 0.000623 & 0.0003 & 0.000407 & 4.672322 & 0.001697 & 0.00035 & 0.001038 & 2.076923 & & & \\
\hline San Andreas B & 0.519127 & 0.519302 & 0.519223 & 2.076306 & 0.519142 & 0.519261 & 0.519068 & 0.519119 & 0.52013 & & \\
\hline San Andreas A & 2.076312 & 2.076467 & 2.076395 & 0.519089 & 2.076369 & 2.076429 & 2.076272 & 0.000033 & 2.07725 & 0.51907 & \\
\hline San Andreas $A^{+}$ & 0.000299 & 0.000093 & 0.000156 & 4.671972 & 0.001123 & 0.000122 & 0.000603 & 2.07659 & 0.000059 & 0.519689 & 2.076829 \\
\hline
\end{tabular}

${ }^{*} \mathrm{~B}<8 \mathrm{~mm} ; \mathrm{A}=$ between 8,1 to $12 \mathrm{~mm} ; \mathrm{A}^{+}>12 \mathrm{~mm}$ 

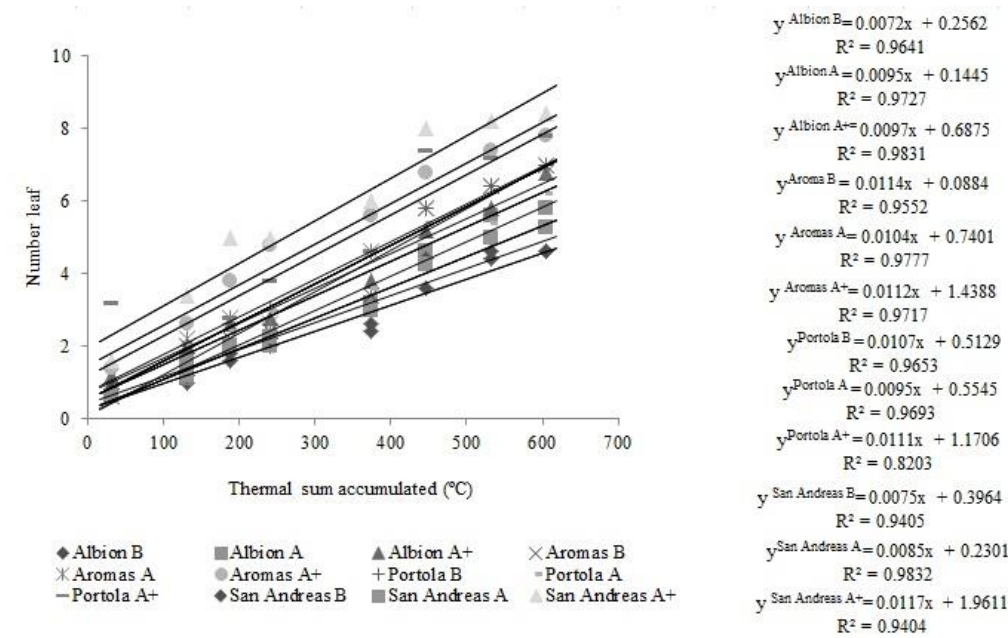

Fig 2. Estimative of phyllochron given by the accumulated thermal time (ATt), Julian days (JD), and number of leaves in the main crown.

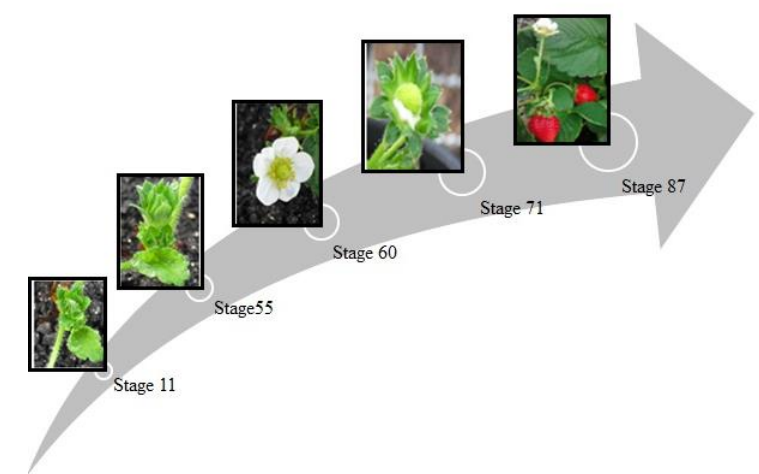

Fig 3. Phenological stages of strawberry considered for evaluation, according to the scale described by Meier et al. (1994). Stage 11, first leaf expanded; stage 55, appearance of first flower primordia at the base of the leaf rosette; stage 60, first open flowers (primary); stage 71, receptacle jutting out from the sepal's crown; stage 87, main crop with most of the fruits red colored.

Table 4. Concentration of macronutrients in nutrient solutions for the cultivation without soil of the strawberry.

\begin{tabular}{llllllll}
\hline & \multicolumn{2}{l}{ Concentration $\left(\mathrm{mmol} \mathrm{L}^{-1}\right)$} & & & \\
\cline { 2 - 8 } Authors & $\mathrm{NO}_{3}^{-}$ & $\mathrm{NH}_{4}^{-}$ & $\mathrm{K}^{+}$ & $\mathrm{H}_{2} \mathrm{PO}_{4}$ & $\mathrm{Ca}^{++}$ & $\mathrm{Mg}^{++}$ & $\mathrm{SO}_{4}^{--}$ \\
\hline Furlani and Fernandes Júnior (2004) & 8.3 & 0.8 & 3.8 & 1.6 & 2.6 & 1.5 & 1.5 \\
Furlani and Fernandes Júnior (2004) & 8.3 & ---- & 4.6 & 1.6 & 2.6 & 1.5 & 1.5 \\
\hline
\end{tabular}

${ }^{1}$ Vegetative phase; ${ }^{2}$ Fruiting phase

and Carneiro, 2003). Accordingly, based on the matrix, it can be inferred that the most promising crossing is between the cultivars Aromas $B$ and Portola $A^{+}$, which present the highest dissimilarity $\left(D^{2}=4.672322\right)$ for precocity. Several methods are available to evaluate the genetic diversity in plant populations (Morales et al., 2011). These differ in their ability to detect differences between genotypes, cost, ease of use, consistency and repeatability of results. The use of morphoagronomic characters in the evaluation of genetic divergence provides a simplified quantification of genetic variation and simultaneously makes it possible to evaluate the performance of genotypes in the growth environment (Malik et al., 2014). In general, morphoagronomic characteristics are efficient when it comes to characterizing cultivars and studying genetic divergence. In strawberry, the shortening of day length and low temperatures causes dormancy. For DN cultivars more specifically, temperature is a determining factor (Durner, 20015). Just before the plant enters dormancy, paralysis of growth occurs along with overproduction of carbohydrates, which are stored in various organs (crown, petiole, primary roots), mainly in the form of starch. It is known that in short-day strawberry cultivars, crown diameter influences the general plant development and precocity of production (Durner, 2016). The present results show that for the DN strawberry cultivars tested, this assertion is also true. In this way, it is emphasized that the use of DN cultivars mainly benefits the producers because the product can be supplied in advance to the consumer market due to the precocity. In addition to this benefit, the use of DN cultivars allows production during off-season, which in the Brazilian subtropics occurs from February to April (Costa et al., 2016). These aspects contribute to increasing profitability for producers. 


\section{Materials and Methods}

\section{Plants and cultivation area}

Seedlings of bare root of four cultivars originating from Llahuen nursery, located in Chilean Patagonia (3350'15.41 "S and 7040'03.06" O) were tested during the period of July to October 2014. The tests were conducted in an agricultural greenhouse with an area of $90 \mathrm{~m}^{2}$ located in the northeastsoutheast direction in the Horticulture Sector of the Faculty of Agronomy and Veterinary Medicine of the University of Passo Fundo, Passo Fundo, Rio Grande do Sul, Brazil (2815'39"S, 5224'33"W). Plants were grown in plastic pots with a capacity of $2 \mathrm{~L}$. The growth substrate was sand. Irrigation was individualized per pot and distributed using the drip system, with flow rate of $1.3 \mathrm{~L}$ per hour. The fertigations solutions used were those described by Furlani and Fernandes Júnior (2004) according to the stage of development of the plant (Table 4). The solutions were administered twice week.

\section{Treatments and experimental design}

Treatments were composed of seedlings of four strawberry cultivars (Albion, Aromas, Portola and San Andreas) and three plant crowns diameters $(\varnothing \mathrm{B}<8 \mathrm{~mm} ; \varnothing \mathrm{A}=8.1$ to 12 $\mathrm{mm} ; \varnothing \mathrm{A}^{+}>12 \mathrm{~mm}$ ) for each of them according Faby (1996). Each plot consisted of 12 plants with five repetitions. The $4 \mathrm{x}$ 3 experiment was distributed in a randomized design, with split plots, where the main plot represented the cultivars and the split plots included the crown diameters.

\section{Procedures}

\section{Phenological stages}

Phenological evaluations consisted of observations and weekly registrations of the different phases of development, from the main stadium, 0 until 8 , corresponding to sprouting and maturation of the fruit, respectively, according to the $\mathrm{BBCH}$ (Biologishe Bundesanstalt, Bundessortenamt and Chemical Industry) coding of the phenological stages of strawberry development as described by Meier (1994).

\section{Thermal sum}

To determine the thermal sum, a Sato brand thermohygrograph was used. This was located inside the agricultural greenhouse at a height of $1.5 \mathrm{~m}$. The data were extracted according to the minimum and maximum air temperature. The daily mean temperature $(\mathrm{dmT})$ was calculated by the following equation: $\mathrm{DmT}=((\mathrm{t} 0+\mathrm{t} 2+\mathrm{t} 3+$ $\ldots \mathrm{t} 22+\mathrm{t} 24) / 12)$. This calculates the arithmetic mean of temperatures $(\mathrm{O} C)$ recorded by the thermo-hygrograph every 2 hours. The daily thermal sum (dTS) was calculated as proposed by Gilmore and Rogers (1958) and Arnold (1960), using the equation: $d T S=(d m T-b T)\left[\stackrel{\circ}{C} d^{d a y}{ }^{-1}\right]$ at where, $\mathrm{dmT}=$ daily mean temperature and $\mathrm{bT}=$ base temperature.

Base temperature is defined as the minimum temperature, below which there is no appearance of leaves. The bT for strawberry was considered to be $7^{\circ} \mathrm{C}$. The dTS was accumulated since the transplantation of seedlings, resulting in thermal sum accumulated (TSa), that is: TSa $=\Sigma$ dTS.

The strawberry cycle was expressed in Julian days (JD) and the cultivation was continued until the maturation of fruits obtained from the primary raceme.

\section{Phyllochron}

To determine phyllochron, the evaluations consisted of counting the leaf number (LN) weekly from the beginning of leaf appearance until the harvest of fruits in the primary raceme. A new leaf was considered to have been emerged when the leaflets became visible at approximately $1 \mathrm{~cm}$ wide.

\section{Data analysis}

For data analysis, some main stages were marked within the strawberry crop. Specifically, at stage 11, the first leaf expanded; stage 55 marked the appearance of the first flower primordia at the base of the leaf rosette. The stage 60 , is the appearance of first open flowers (primary). At stage 71 , a receptacle was seen to be jutting out from the sepal's crown; and at stage 87 , the main crop had grown and most of the fruits were red colored (Fig 3).

The phenological data were subjected to multivariate analysis, calculating the Mahalanobis distance $\left(D^{2}\right)$ and Tocher's optimization method to quantify the dissimilarities between treatments. This analysis was carried out using the Genes Software (Cruz, 2001).

To estimate the phyllochron, a linear regression was carried out between the LN in the main crown and the TSa. The phyllochron ( $\left(-\mathrm{C}\right.$ day leaf ${ }^{-1}$ ) was estimated as the inverse angular coefficient of the linear regression.

\section{Conclusion}

The morpho-agronomic variability between DN strawberry cultivars is associated with precocity of the crop, especially Aromas $\mathrm{A}^{+}$and San Andreas $\mathrm{A}^{+}$with harvest anticipated in 13 days. The variability between groups is evidenced mainly by stage 71 , when the receptacle had emerged from the sepal's crown. The quality of the seedling verified by the crown diameter, greater than $8.1 \mathrm{~mm}$, is determinant for the precocity of DN strawberry cultivars. This study could help producers to select DN strawberry cultivars that start production in advance, giving them greater profitability.

\section{Acknowledgements}

The authors thank Capes, Fapergs and CNPq for granting scholarships.

\section{References}

Akhatoua I, González-Domíngueza R, Fernández-Recamalesa A (2016) Investigation of the effect of genotype and agronomic conditions on metabolomics profiles of selected strawberry cultivars with different sensitivity to environmental stress. Plant Physiol Biochem. 101(1): 1422. 
Arnold CY (1960) Maximum-Minimum temperature as a basis for computing heat units. Am Soc Hortic Sci. 76: 682692.

Bartczak M, Lisiecka J, Knaflewski M (2010) Correlation between selected parameters of planting material and strawberry yield. Folia Hortic. 22(1): 9-12.

Bertan I, Carvalho FIF, Oliveira AC, Silva AG, Benin G, Vieira EA, Silva GO, Hartwig I, Valério IP, Finatto T (2006) Dissimilaridade genética entre genótipos de trigo avaliados em cultivo hidropônico sob estresse por alumínio. Bragantia. 65(1): 55- 63.

Cascaes MF, Citadini-Zanette V, Harter-Marques B (2013) Reproductive phenology in a riparian rainforest in the south of Santa Catarina state, Brazil. An Acad Bras Cienc. 85(4): 1449-60.

Costa RC, Calvete EO, Mendonça HFC, Campagnolo AP, Chiomento JLT (2016) Performance of day-neutral strawberry cultivars in soilless culture. Aust J Crop Sci. 10(1): 94-100.

Costa RC, Calvete EO, Mendonça HFC, Decosta LA (2014) Phenology and leaf accumulation in vernalized and nonvernalized strawberry seedlings in neutral-days. Acta Sci Agron. 36(1): 57-62.

Cruz CD (2001) Programa GENES: aplicativo computacional em genética e estatística. Viçosa. 20ำ Ed. Editora UFV, Minas Gerais, Brasil.

Cruz CD, Carneiro PCS (2003) Modelos biométricos aplicados ao melhoramento genético. Viçosa, Editora UFV, Brasil.

Dávalos-González PA, Jofre-Garfías AE, Vázquez-Sánchez MN, Hernández-Razo R (2014) Macrotunnel, plant type and genotype effect on strawberry precocity and productivity in irapuato, GTO. Mexico. Acta Hortic.1049: 801-807.

Durner EF (2015) Photoperiod affects floral ontogeny in strawberry (Fragaria $\mathrm{x}$ ananassa Duch.) plug plants. Sci Hortic. 194: 154-159.

Durner EF (2016) Photoperiod and temperature conditioning of 'Sweet Charlie' strawberry (Fragaria x ananassa Duch.) plugs enhances off-season production. Sci Hortic. 201: 184-189.

Faby R (1996) The productivity of graded "Elsanta" frigo plants from different origin. Acta Hortic. 439: 449-455.

Frank AB, Bauer A (1995) Phyllochron differences in wheat, barley, and forage grasses. Crop Sci. 35(1): 19-23.

Furlani PR, Fernandez Júnior F (2004) Cultivo hidropônico de morango em ambiente protegido. Trabalho apresentado no 2o Simpósio Nacional do Morango e Encontro de Pequenas Frutas e Frutas Nativas do Mercosul, Embrapa Clima Temperado, Pelotas, 102-115, 2004.

Gilmore ECJr, Rogers JS (1958) Heat units as a method of measuring maturity in corn. Agron J. 50(10): 611- 615.

Gonçalves GAF, Resende NA, Gonçalves CS, Alcantara EM, Carvalho EEN, Resende JV (2017) Temporal dominance of sensations for characterization of strawberry pulp subjected to pasteurization and different freezing methods. LWT - Food Sci Technol. 77: 413-421.

Hermes CC, Medeiros SLP, Manfron PA, Caron B, Pommer SF, Bianchi C (2001) Emissão de folhas de alface em função da soma térmica. Rev Bras Agromet. 9(2): 269-275.

Hidaka K, Dan K., Imamura H, Takayama T (2017) Crowncooling treatment induces earlier flower bud differentiation of strawberry under high air temperatures. Environ Control Biol. 55(1): 21-27.

Ledesma NA, Kawabata S (2016) Responses of two strawberry cultivars to severe high temperature stress at different flower development stages. Sci Hortic. 21: 319327.

Malik R, Sharma H, Sharma I, Kundu S, Verma A, Sheoran S, Rajendra K, Ravish C (2014) Genetic diversity of agromorphological characters in Indian wheat varieties using GT biplot. Aust J Crop Sci. 8(9): 1266-1271.

Meier U (1994) Codificación BBCH de los estádios fenológicos de desarrollo de la fresa. http://www.bba.de/veroeff/ bbchspa.pdf (Acessado em: 10 de junho de 2005).

Morales RGF, Resende JTV, Faria MV, Andrade MC, Resende LV, Delatorre CA, Silva PR (2011) Genetic similarity among strawberry cultivars assessed by RAPD and ISSR markers. Sci Agric. 68(6): 665-670.

Rahman MM, Saha MG, Islam MN, Ullah MA, Quamruzzaman AKM (2016) Phenology and yield of strawberry as influenced by planting time and genotypes in a sub tropical region. Pak J Sci Ind Res. Series B: Biological Science. 59(3): 126-132.

Rosa HT, Walter LC, Streck NA, Andriolo JL, Silva MR, Langner JÁ (2011) Base temperature for leaf appearance and phyllochron of selected strawberry cultivars in a subtropical environment. Bragantia. 70(4): 939-945.

Rosa HT, Streck NA, Walter LC, Andriolo JL, Silva MR (2013) Crescimento vegetativo e produtivo de duas cultivares de morango sob épocas de plantio em ambiente subtropical. Rev Ciênc Agron. 44(3): 604-613.

Sønsteby A, Heide OM (2007) Long-day control of flowering in everbearing strawberries. J Hortic Sci Biotechnol. 82: 875- 884.

Sønsteby A, Solhaugb KA, Heide OM (2016) Functional growth analysis of 'Sonata' strawberry plants grown under controlled temperature and daylength conditions. Sci Hortic. 211: 26- 33.

Torres-Quezada EA, Zotarelli L, Whitaker VM, Santos BM, Hernandez-Ochoa I (2015) Initial crown diameter of strawberry bare-root transplants affects early and total fruit yield. Horttechnology. 25(2): 203-208.

Wan $\mathrm{H}$, Liang YP, Zhong L, Kong LM, Liu JX, Gao ZQ, Wang LR, Tao P (2014) Performance of twelve introduced strawberry cultivars in Kunming, Yunnan province. Acta Hortic. 1059: 127-132. 